\title{
Miscanthus ash melting: comparison of thermodynamic calculation and experiments in thermal processes
}

\author{
J. Kaknics $^{1}$, R. Michel ${ }^{1}$, M-L. Bouchetou ${ }^{1,2}$, and J. Poirier ${ }^{1,2}$ \\ ${ }^{1}$ CEMHTI CNRS UPR 3079, Orléans, France \\ ${ }^{2}$ Université d'Orléans, Orléans, France
}

\section{Introduction}

For over 30 years researchers have been investigating biomass ash transformation during different thermal processes to better understand slagging, fouling and agglomeration phenomena. During the thermal conversion of biomass, inorganics of the plant can transform or volatilise, condense in the flue gas channel and on the surface of heat exchangers resulting in slagging and fouling. It is also possible that part of the volatilised inorganic and other non-volatile inorganics react with the bed material in the reactor leading to agglomeration. Elements which are in ionic form in the plant (alkaline, $\mathrm{S}, \mathrm{Cl}$ ) can leave the reactor with the flue gas (fly ash) and form deposit of salts, while silicates mostly remain in the reactor (bottom ash) and they can form viscous melts of oxides and agglomerates [1]. Therefore, it is important to predict the temperature of ash fusion and volatilisation of a given biomass before considering it as a biofuel. Energy crops such as miscanthus are good candidates due to their high heating value and resistance to different climates, though their high silica and potassium content has to be taken into account as these compounds can form low melting point silicates at relatively base temperature $\left(<800^{\circ} \mathrm{C}\right)$.

Ash fusibility test is a widely used method in industry to determine the phase transformation of the ash. Besides, many studies have been carried out about predicting the inorganic phase transition by calculating thermodynamic equilibrium [2-4]. However, these results must be interpreted with care as equilibrium state usually cannot be reached in industrial applications as the transformation time is too short ${ }^{2}$. Identifying and quantifying the inorganics in miscanthus samples involves certain challenges due to the small quantity of ash forming elements in the plant, the variety of inorganic compounds, and their appearance both in crystalline and amorphous form. The aim of this study is to compare the thermodynamic model calculations with laboratory tests as a first step to evaluate their accuracy for describing phase transition and ash melting of miscanthus.

\section{Experiments}

The Miscanthus X Giganteus sample was supplied by NovaBiom (harvest in April 2011 in La Ferté Chevresis, France). The ultimate analysis of miscanthus and the ash fusibility test (oxidising atmosphere, on ash $815^{\circ} \mathrm{C}$, CEN/TS 15370-1 standard) was done by SOCOR Laboratory.

For our laboratory experiments, ash was prepared by burning dried miscanthus at $400^{\circ} \mathrm{C}$ in an open muffle furnace for eight hours. This relatively low temperature was chosen to densify the inorganic content without major modification of inorganic phases. The ash obtained at $400^{\circ} \mathrm{C}$ was homogenised by mortar grinder (Fritsch Pulverisette, type 02.102); this was the start-up sample for further high temperature experiments. The phase transition of ash was studied by differential scanning calorimetry (DSC, SETARAM S60/36000).

To investigate the transformation of inorganics in ash, samples were heat-treated for one hour at $1000^{\circ} \mathrm{C}$ in a laboratory furnace (Nabertherm $30-30-3000^{\circ} \mathrm{C}, \mathrm{N} 7 / \mathrm{H}$, heating rate $5^{\circ} \mathrm{C} / \mathrm{min}$, stationary air). The chemical composition was determined by energy dispersive spectroscopy (SEM-EDS, F.E.I., XL 40 TMP ESEM) with cobalt reference. The data were obtained with software developed by Oxford Instruments.

The crystalline phases of ash samples were examined by X-ray diffraction (XRD, Brucker D8 Advance (cathode $\mathrm{Cu}, \mathrm{K} \alpha 1=1.5406 \AA$, $12-70^{\circ}$, detector open at $5^{\circ}$, step $0.0164^{\circ}$, scan speed $=2 \mathrm{~s} / \mathrm{scan}, 30 \mathrm{kV}, 40 \mathrm{~mA}$, div split 0.7 , rotation $15 \mathrm{mps}$, sample holder: Si hollow).

\section{Modeling}

We performed thermodynamic calculations with Factsage $6.3 \circledR$ based on the ultimate analysis of the plant. Factsage $6.3 \circledR$ contains evaluated compound and software databases. The equilibrium state is calculated by minimizing the Gibbs energy. The combustion of $1 \mathrm{~kg}$ of miscanthus with stoichiometric amount of oxygen at 1 atm between 400 and $1000^{\circ} \mathrm{C}$ was calculated using FactPS, FToxid, and FTsalt. The compounds selected 
were $\mathrm{C}, \mathrm{H}, \mathrm{O}, \mathrm{N}, \mathrm{S}, \mathrm{Cl}, \mathrm{Si}, \mathrm{Ca}, \mathrm{Mg}, \mathrm{K}, \mathrm{P}$ and $\mathrm{Na}$. Minor elements in miscanthus ash $(\mathrm{Mn}, \mathrm{Fe}, \mathrm{Ti}$ and $\mathrm{Al})$ were excluded. The chosen model consists of liquid (FToxidslagB) and solid solution phases (FToxid-WOLLA, FToxid-CPyrA, FTsalt-CSOB).

\section{Results}

\subsection{Experiments}

The main steps of ash fusibility test are:

- $\quad$ shrinkage starting temperature: $902^{\circ} \mathrm{C}$

- deformation temperature: $968^{\circ} \mathrm{C}$

- hemisphere temperature: $1118^{\circ} \mathrm{C}$

- flow temperature: $1326^{\circ} \mathrm{C}$

We can compare this test with the DSC curve of ash in air (Figure 1.). In the DSC curve there are two peaks at 425 and $755^{\circ} \mathrm{C}$ which correspond to phase transitions. The fusion of ash starts around $950^{\circ} \mathrm{C}$ which is close to the deformation temperature in the ash fusibility test $(968$ $\left.{ }^{\circ} \mathrm{C}\right)$. The total fusion in DSC curve is at $1380^{\circ} \mathrm{C}$ which corresponds to the flow temperature in the fusibility test $\left(1326^{\circ} \mathrm{C}\right)$.

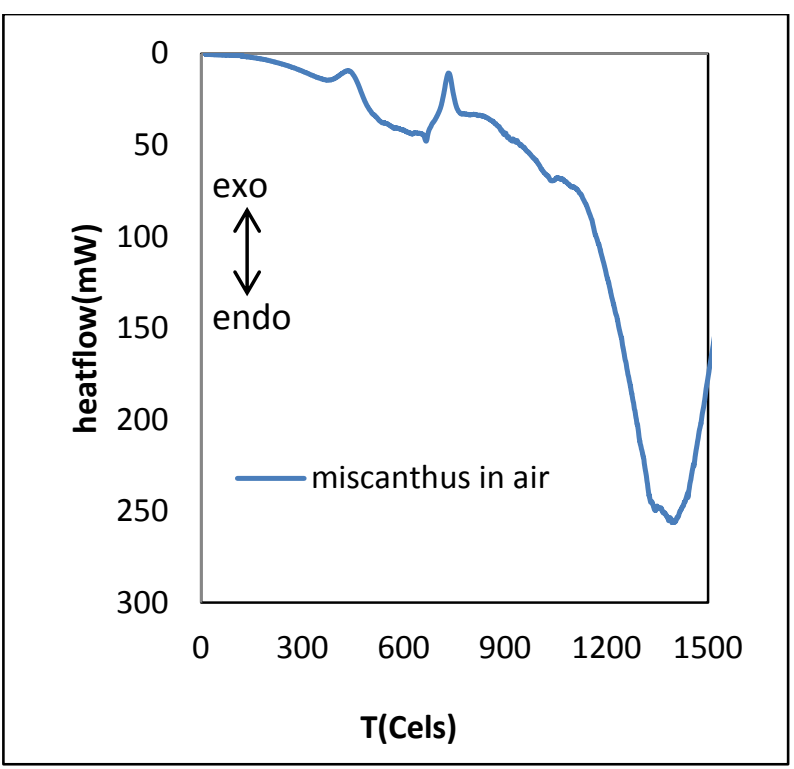

Figure 1. DSC in air of miscanthus ash sample.

As the ash contains both crystalline and amorphous phases, different methods were used for analysis. The ash sample prepared at $400^{\circ} \mathrm{C}$ still contained organic carbon which disturbs the SEM measurement; hence precise quantitative analysis could not be done.

The crystalline compounds at $400^{\circ} \mathrm{C}$ and $1000^{\circ} \mathrm{C}$ were determined by XRD (Figure 2). The main compounds of ash prepared at $400^{\circ} \mathrm{C}$ are $\mathrm{K}_{2} \mathrm{SO}_{4}, \mathrm{SiO}_{2}, \mathrm{KCl}, \mathrm{CaCO}_{3}$ and different hydrated forms of Ca-phosphate. After heattreatment at $1000^{\circ} \mathrm{C}$, the peaks of $\mathrm{K}_{2} \mathrm{SO}_{4}, \mathrm{SiO}_{2}$ and $\mathrm{KCl}$ were still present but their intensity declined, while the peaks of $\mathrm{CaCO}_{3}$ disappeared. We observed the formation of $\mathrm{CaSiO}_{3}$ according to the reaction (1):

$\mathrm{SiO}_{2}+\mathrm{CaCO}_{3} \rightarrow \mathrm{CaSiO}_{3}+\mathrm{CO}_{2}$
The amorphous phase was studied by SEM-EDS. Figure 3 shows an ash sample heat-treated at $1000^{\circ} \mathrm{C}$. A grain of silica is surrounded with molten phase which contains mainly $\mathrm{Si}, \mathrm{K}, \mathrm{Ca}$ and a small amount of $\mathrm{Mg}$ and $\mathrm{Na}$ (Table 1).

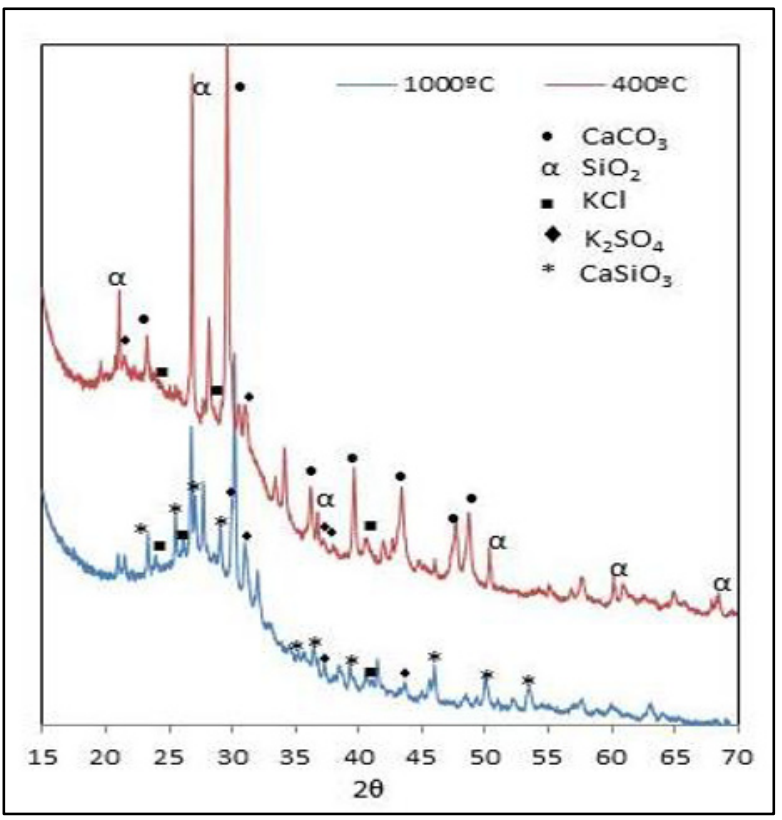

Figure 2. XRD of ash at 400 and $1000^{\circ} \mathrm{C}$.

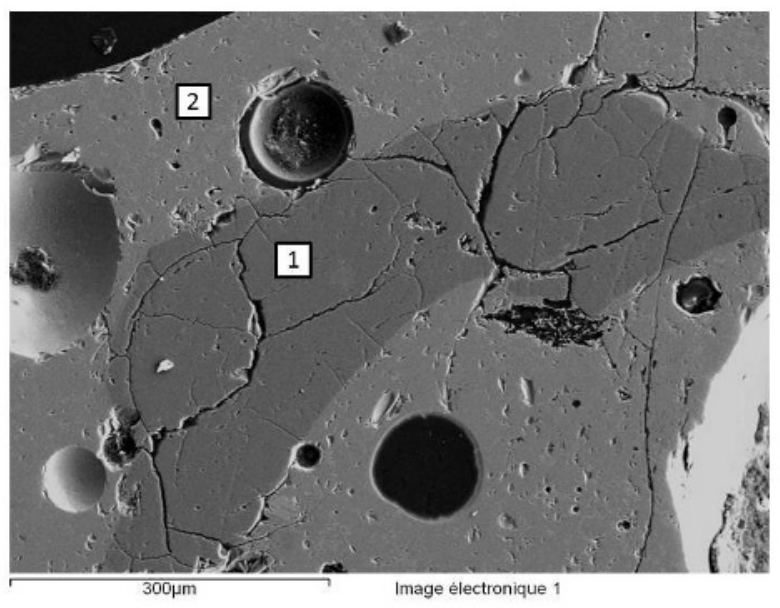

Figure 3. Ash sample at $1000^{\circ} \mathrm{C}$.

Table 1. EDS analysis of ash sample heat treated at $1000^{\circ} \mathrm{C}$.

\begin{tabular}{|l|l|l|l|l|l|l|l|}
\hline & $\mathrm{O}$ & $\mathrm{Na}$ & $\mathrm{Mg}$ & $\mathrm{Si}$ & $\mathrm{K}$ & $\mathrm{Ca}$ & Total \\
\hline 1 & 55.4 & 0.0 & 0.0 & 44.3 & 0.0 & 0.4 & 100 \\
\hline 2 & 46.3 & 0.5 & 2.0 & 31.4 & 11.6 & 8.2 & 100 \\
\hline
\end{tabular}

\subsection{Model calculation}

Figure 4 shows the amount of main ash forming compounds in function of temperature calculated by Factsage $6.3 \AA$. Similarly to the laboratory tests, the amount of $\mathrm{K}_{2} \mathrm{SO}_{4}, \mathrm{SiO}_{2}$ and $\mathrm{KCl}$ declines. In contrast to 
our test, $\mathrm{KCl}$ and $\mathrm{K}_{2} \mathrm{SO}_{4}$ are not present in solid phase at $1000^{\circ} \mathrm{C}$ in equilibrium.

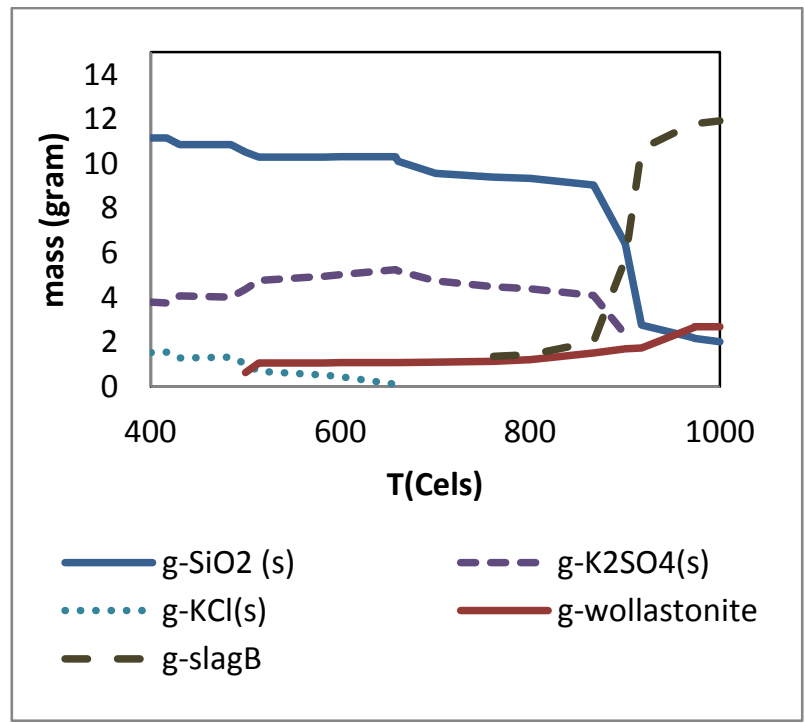

Figure 4. Main ash forming compounds in function of temperature.

Figure 5 shows the ratio of liquid to solid phase ratio $(\mathrm{L} /(\mathrm{S}+\mathrm{L}))$ in ash. The liquid phase, slag appears at $761^{\circ} \mathrm{C}$ and its quantity significantly increases at high temperature; $60 \%$ of the ash is molten at $1000^{\circ} \mathrm{C}$. At $1275^{\circ} \mathrm{C}$ the different silicates melt hence the ratio sharply reaches $97 \%$. The only stable solid compound is $\mathrm{Ca}_{3}\left(\mathrm{PO}_{4}\right)_{2}$.

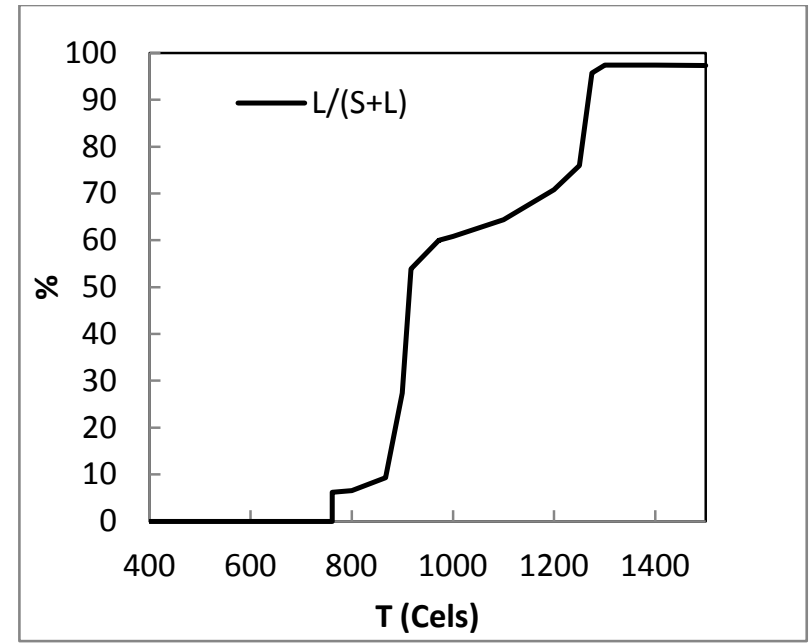

Figure 5. Liquid to solid ratio in function of temperature.

Table 2 summarizes the composition of slag at high temperature $\left(800-1000^{\circ} \mathrm{C}\right)$. The slag is composed of $\mathrm{SiO}_{2}$ and $\mathrm{K}_{2} \mathrm{O}$ with a ratio of 2.5 . The amount of $\mathrm{SiO}_{2}$ slightly increases as more silica melts at high temperature and the amount of $\mathrm{K}_{2} \mathrm{O}$ decreases as potassium volatilises.
Table 2. Composition of liquid phase at $1000^{\circ} \mathrm{C}$.

\begin{tabular}{|c|c|c|}
\hline \multicolumn{3}{|c|}{$1000^{\circ} \mathrm{C}$} \\
\hline$w t \%-\mathrm{Na}_{2} \mathrm{O}$ & $\mathrm{wt} \%-\mathrm{SiO}_{2}$ & $\mathrm{wt} \%-\mathrm{K}_{2} \mathrm{O}$ \\
\hline 2 & 77 & 21 \\
\hline
\end{tabular}

\subsection{Comparison of model with experiments}

According to the calculation liquid phase appears at $761^{\circ} \mathrm{C}$. In ash fusion test the shrinkage starting temperature is quite high $\left(902^{\circ} \mathrm{C}\right)$. The difference can be due to the different techniques, DSC is a sensitive measurement of heat flow while the ash fusibility test is based on visual observation. At $1000^{\circ} \mathrm{C}$ the $\mathrm{L} /(\mathrm{S}+\mathrm{L})$ reaches $60 \%$ in calculation. This fits quite well to the starting point of the fusion in the DSC curve and to the deformation temperature in ash fusion test $\left(968^{\circ} \mathrm{C}\right)$. At $1275^{\circ} \mathrm{C}$ the ash fusion is almost complete $(\mathrm{L} /(\mathrm{S}+\mathrm{L})>97 \%)$, but the temperature of liquidus is quite high due to the high melting point of $\mathrm{Ca}_{3}\left(\mathrm{PO}_{4}\right)_{2}$. The minimum point of the fusion in DSC curve is at $1380^{\circ} \mathrm{C}$, while the flow temperature is $1326^{\circ} \mathrm{C}$.

It is quite difficult to describe the exact ash composition from the diffractograms, as the ash contains several inorganic compounds in low quantity and in amorphous form. However, some tendency can be drawn for the main compounds in the ash and we get comparable results with thermodynamic calculation. The most important compounds are $\mathrm{SiO}_{2}, \mathrm{~K}_{2} \mathrm{SO}_{4} \mathrm{KCl}$, $\mathrm{CaSiO}_{3}$. Their presence can also be proven by calculation. $\mathrm{CaCO}_{3}$ can be detected by XRD but it is not calculated in the equilibrium state. Different forms of calcium phosphates are probably present but they ash has to be further analysed to properly certify their presence.

Table 3. Comparing the different compounds in XRD and thermodynamic calculation in combustion $(\checkmark-$ detected/calculated).

\begin{tabular}{|l|l|l|}
\hline & XRD & FactSage \\
\hline $\mathrm{SiO}_{2}$ & $\checkmark$ & $\checkmark$ \\
\hline $\mathrm{KCl}$ & $\checkmark$ & Not at $1000^{\circ} \mathrm{C}$ \\
\hline $\mathrm{K}_{2} \mathrm{SO}_{4}$ & $\checkmark$ & $\checkmark$ \\
\hline $\mathrm{CaCO}_{3}$ & $\checkmark$ & Not calculated \\
\hline $\mathrm{CaSiO}_{3}$ & $\checkmark$ & $\checkmark$ \\
\hline $\mathrm{Ca}_{3}\left(\mathrm{PO}_{4}\right)_{2}$ & $\checkmark$ & $\checkmark$ \\
\hline
\end{tabular}




\section{Conclusion}

In this study we compared the equilibrium calculations with laboratory experiments (DSC, DRX, ash fusibility test, SEM) of miscanthus ash melting. We found that the chosen model correlates well with the ash fusibility test. Moreover, we elucidated the presence of different inorganic compounds $\left(\mathrm{KCl}, \mathrm{SiO}_{2}, \mathrm{~K}_{2} \mathrm{SO}_{4}, \mathrm{CaSiO}_{3}\right.$ and $\left.\mathrm{Ca}_{3}\left(\mathrm{PO}_{4}\right)_{2}\right)$.

In our laboratory tests we found that the liquid phase appears at $755^{\circ} \mathrm{C}$, the ash fusion becomes visible above $900^{\circ} \mathrm{C}$ and the ash totally melts at $1380^{\circ} \mathrm{C}$. However, some limitations have to be noted. As the ash contains many different compounds in small quantities both in amorphous and crystalline forms, it is quite difficult to analyse the diffractograms, determine and quantify all the compounds and make comparison with equilibrium calculations.

\section{References}

1. M. Zevenhoven-Onderwater, R. Backman, B.J. Skrifvars, M. Huppa, Fuel 801489 (2001)

2. D. Lindberg, R. Backman, P. Chartrand, M. Hupa, Fuel Process Technol. 105129 (2013)

3. H. Li, N. Yoshihiko, Z. Dong, M. Zhang, Chinese J. Chem. Eng. 14960784 (2006)

4. N. Evic, Th. Brunner, I. Obernberger, $20^{\text {th }}$ European Biomass Conference and Exhibition, 18-22 June 2012, Milan, Italy. 